JPBIO (Jurnal Pendidikan Biologi)

Vol. 2 No. 2 November 2017 | 6 - 14

ISSN 2540-802x (Online)

DOI: http://dx.doi.org/10.31932/ JPBIO (Jurnal Pendidikan Biologi)

http://jurnal.stkippersada.ac.id/jurnal/index.php/JBIO

\title{
PENGARUH METODE GROUP TO GROUP EXCHANGE BERBANTUAN MEDIA GAMBAR TERHADAP HASIL BELAJAR KOGNITIF SISWA PADA MATERI EKOSISTEM
}

\author{
Natalia Septilianti ${ }^{1}$, Benediktus Ege ${ }^{2^{*}}$, Hendrikus Julung ${ }^{3}$ \\ ${ }^{1}$ Mahasiswa Program Studi Pendidikan Biologi, STKIP Persada Khatulistiwa Sintang \\ 2,3Dosen Program Studi Pendidikan Biologi, STKIP Persada Khatulistiwa Sintang \\ E-mail: nataliaseptilianti@yahoo.co.id,ama_tamo@yahoo.com*, \\ henjulung@gmail.com
}

Diterima: 15 Mei 2017

Direvisi: 05 Juni 2017

Disetujui: 19 Oktober 2017

\begin{abstract}
ABSTRAK
Penelitian ini bertujuan untuk mengetahui pengaruh metode group to group exchange berbantuan media gambar terhadap hasil belajar kognitif siswa pada materi ekosistem di kelas VII Sekolah Menengah Pertama Negeri 4 SekadauHilir. Variabel bebas dalam penelitian ini adalah metodegroup to group exchange dengan media gambar dan variabel terikat adalah hasil belajar kognitif. Pendekatan yang digunakan dalam penelitian adalah kuantitatip. Metode yang diterapkan dalam penelitian ini adalah metode Eksperimen. Bentuk penelitian adalah penelitian Quasi Experimental Design. Desain penelitian yang digunakan adalah Nonequivalent Control GroupDesign. Populasi dalam penelitian adalah seluruh siswa kelas VII SMP Negeri 4 Sekadau Hilir yang berjumlah 57 siswa. Sampel dalam penelitian ini kelas VII A sebagai kelas eksperimen dengan jumlah 28 siswa dan kelas VII B sebagai kelas kontrol dengan jumlah 29 siswa. Teknik sampling yang digunakan adalah Sampling Jenuh. Teknik pengumpulan data yang digunakan adalah teknik observasi langsung, teknik pengukuran, dan teknik komunikasi tidak langsung. Alat pengumpulan data yang digunakan adalah lembar observasi, soal tes, dan angket. Data yang diperoleh menunjukan proses pembelajaran berlangsung dengan persentase $100 \%$. Nilai hasil belajar kognitif diperoleh nilai rata-rata pretest pada kelas eksperimen 40,80 dan kontrol 39,52. Uji U Mann Whitney data pretest menunjukan $-Z_{\text {tabal }}<Z_{\text {hitung }}<Z_{\text {tabel }}(-1,96<-0,83<1,96)$ maka Ho diterima. Hasil posttest pada kelas eksperimen dengan rata-rata 84,93 dan kontrol 72,26. Uji hipotesis data posttest menggunakan uji $U$ Mann Whitney menunjukan $-Z_{\text {hitung }}<Z_{\text {tabel }}(-5,79>-1,96)$ maka Ha diterima. Hasil angket menunjukan kriteria kuat $85,92 \%$. Disimpulkan bahwa terdapat pengaruh yang signifikan penggunaan metode group to group exchange berbantuan media gambar terhadap hasil belajar kognitif siswa pada materi ekosistem di kelas VII Sekolah Menengah Pertama Negeri 4 Sekadau Hilir.
\end{abstract}

Kata Kunci: group to group exchange, media gambar, hasil belajar kognitif, dan ekosistem.

\section{ABSTRACT}

The objective of this study was to determine the influence of group to group exchange method with picture assisted on students' cognitive learning achievement on learning 
material ecosystem at class VII Sekolah Menengah Pertama Negeri 4 SekadauHilir in the academic year 2016/2017. There were two variables in this research namely free and bound variable. The free variable was "Group to Group Exchange Method with Picture Assisted" and the bound variable was "student cognitive learning result". The approach used in this study there is a quantitative approach. Method applied in research is experiment method. The research method used in this research was quasi experiment with nonequivalent control group design. Population in this research was all students class IX Sekolah Menengah Pertama Negeri 4 Sekadau Hilir consisting of class VII A and class VII B. The sample in this research was class VII $A$ as experiment class totaling 28 students and class VII $B$ as control class totaling 29 students. Sampling technique used was purposive sampling technique. The data collecting techniques used was direct observation technique; measurement technique and indirect communication technique, meanwhile the instruments used to collect the data were observation sheets, questions test and questionnaires. The result of the data analysis showed that the learning process was $100 \%$. The student's cognitive learning achievement obtained from post-test was 40,80 and the control class was 39,52. The U Mann Whitney's test showed that $-Z_{\text {table }}<Z_{\text {count }}<Z_{\text {table }}(-1,96<0,83<1,96)$ so that $H$ Ho was accepted. Meanwhile, the hypothesis test on post-test using $U$ Mann Whitney's test showed that $Z_{\text {count }}<Z_{\text {table }}(-5,79<-1,96)$ so Ha was accepted. Hence, it could be concluded that the application of group to group exchange method with picture assisted has a significant effect on students' cognitive learning achievement in the learning material ecosystem at class VII SekolahMenengahPertamaNegeri 4 SekadauHilir.

Keywords: group to group exchange, picture media, cognitive learning, and ecosystem

\section{PENDAHULUAN}

Undang-undang No.20 Tahun 2003, bahwa pendidikan merupakan usaha sadar dan terencana untuk mewujudkan susana belajar dan proses pembelajaran agar perserta didik secara aktif mengembangkan potensi dirinya untuk memilki kekuatan spiritual keagamaan, pengendalian diri, kepribadian, kecerdasan, akhlak mulia, serta keterampilan yang diperlukan dirinya. Selanjutnya dinyatakan bahwa pendidikan nasional mengembangkan potensi peserta didik dalam masyarakat bangsa dan negara Indonesia.

Pendidikan adalah hal yang sangat penting untuk diberikan kepada setiap insan manusia baik pendidikan dari keluarga, sekolah dan masyarakat. Pendidikan berperan penting dalam mengembangkan potensi, sehingga pendidikan menjadi modal utama untuk kemajuan setiap manusia. Hal ini sejalan dengan pendapat Huda (2012: 9), "Pendidikan di Indonesia saat ini yang sedianya merupakan benteng utama dalam mencerdaskan anak bangsa, ternyata tidak mampu berjalan secara optimal dan sangat jauh dari harapan bersama".

Menurut Puspitasari (2012: 2) "Aspek kualitas pendidikan di Indonesia masih sangat memprihatinkan dibandingkan dengan kualitas pendidikan bangsa lain. Salah satu sarana yang dipakai untuk memfasilitasi pendidikan di Negara ini adalah sekolah". Sekolah-sekolah tersebut jauh dari harapan. Saat ini sekolah justru dijadikan sebagai komoditas untuk mendapatkan keuntungan yang sebesar-besarnya.

Masalah rendahnya mutu pendidikan tidak terlepas dari masalah rendahnya kualitas guru hal ini akan berdampak langsung terhadap kualitas pembelajaran serta akan berdampak pada prestasi siswa. Prestasi siswa sebenarnya hasil dari pembelajaran(Ibrahim, 2003: 13).

Menurut Purwanto (2007: 84), Permasalahan pendidikan selalu muncul bersama dengan berkembang dan meningkatnya kemampuan siswa, situasi dan kondisi lingkungan yang ada, pengaruh informasi dan kebudayan, serta berkembangnya ilmu pengetahuan dan teknologi. Oleh sebab itu guru merupakan kunci dari pencapaian misi pemberharuan pendidikan.

Berdasarkan hasil praobservasi pada tanggal 24 Maret 2017 dengan guru mata pelajaran IPA kelas VII di Sekolah Menengah Pertama Negeri 4 Sekadau Hilir ditemukan bahwa pada pembelajaran IPA masih banyak siswa yang kurang mampu menguasi materi 
pembelajaran. Hal ini terlihat dengan rendahnya hasil belajar kognitif siswa yang tidak mencapai Kriteria Ketuntasan Minimal (KKM) yang ditetapkan oleh Sekolah Menengah Pertama 4 Sekadau Hilir untuk mata pelajaran IPA yaitu 75. Berdasarkan hasil ulangan umum bersama semester ganjil terdapat $45 \%$ siswa kelas VII mendapatkan nilai tidak tuntas. Menurut guru bidang studi IPA kelas VII hal ini dikarenakan proses pembelajaran masih didominasi oleh guru, sementara siswa pasif dan kesulitan memahami materi yang dipelajari. Banyak siswa yang kurang percaya diri pada saat guru bertanya tentang materi, lebih sering diam dari pada menjawab pertanyaan guru. Faktor yang mempengaruhi keadaan tersebut adalah kurangnya penggunaan metode pembelajaran yang bervariasi sehingga siswa terlihat kurang aktif.

Selain itu, berdasarkan informasi yang didapat dari beberapa siswa kelas VII Sekolah Menengah Pertama Negeri 4 Sekadau Hilir bahwa guru yang mengajar IPA kurang menggunakan metode pembelajaran yang bervariasi dalam penyampaian materi. Lebih dominan menggunakan metode ceramah. Menurut Aqib (2016: 38), "Metode ceramah merupakan metode yang membuat siswa menjadi pasif, cepat lelah, bosan, mengantuk, kuantitas dan kualitas daya serap siswa terhadap bahan yang diajarkan sangat bervariasi di antara siswa yang satu dengan siswa yang lain".

Perkembangan ilmu pengetetahuan dan teknologi menuntut peningkatan mutu pendidikan yang dapat dilakukan dengan perbaikan, perubahan dan pembaruan terhadap aspek-aspek yang mempengaruhi keberhasilan pendidikan. Aspek-aspek yang mempengaruhi keberhasilan pendidikan meliputi kurikulum, sarana, dan prasarana, guru, siswa, dan metode belajar mengajar. Keberhasilan suatu proses belajar mengajar selain memahami materi juga dituntut mengetahui posisi awal siswa sebelum mengikuti pelajaran. Guru dapat menggunakan pendekatan pembelajaran secara tepat yang diharapkan dapat membantu siswa dalam pengembangan kemampuan kognitifnya.

Menurut Bloom (Sudjana, 2009: 22), "Mengklasifikasikan hasil belajar siswa secara garis besar menjadi tiga ranah yaitu, ranah kognitif, afektif dan pisikomotoris". Ketiga ranah tersebut yang digunakan penelitian ini adalah ranah kognitif. Hal ini berhubungan erat dengan kemampuan berpikir.

Salah satu cara untuk meningkatkan hasil belajar kognitif siswa, guru harus mampu mendesain proses pembelajaran yang inovatif dengan menerapkan berbagai metode pembelajaran yang mampu meningkatkan minat belajar siswa pada akhirnya dapat meningkatkan hasil belajar kognitif yang melibatkan siswa secara aktif. Dalam hal ini, guru dapat menerapkan strategi pembelajaran yang sesuai dengan materi pembelajaran yang akan diberikan. Strategi pembelajaran aktif tipe Group to Group Exchange dapat dijadikan pilihan dalam pelajaran IPA khususnya pada materi Ekosistem, karena akan menjadikan siswa lebih aktif dalam proses belajar dan pembelajaran.

Menurut Silberman (2009: 105) "Strategi pembelajaran aktif tipe Group to Group Exchange merupakan pembelajaran yang berpegang pada konsep belajar aktif (active learning) yang merupakan langkah cepat, menyenangkan, mendukung, dan menarik. Metode pembelajaran Group to Group Exchange merupakan gabungan dari metode diskusi, tanya jawab, dan pengajaran teman sebaya". Guru dapat menggunakan media pembelajaran dalam penyampaian materi pembelajaran untuk menyempurnakan proses pembelajaran pada metode Group to Group Exchange.

Media pembelajaran digunakan sebagai alat bantu untuk mempermudah dan membantu tugas guru dalam menyampaikan berbagai bahan dan materi pelajaran, serta mengefektifkan dan mengefisienkan peserta didik dalam memahami materi dan bahan pembelajaran (Indriana, 2011: 105).

Media membantu tugas guru dalam menyampaikan pesan-pesan dari bahan pembelajaran yang diberikan guru kepada siswa. Tanpa bantuan media maka bahan pembelajaran susah untuk dipahami siswa, terutama untuk bahan yang pelajarannya rumit. Setiap materi memiliki tingkat kesulitan yang bervariasi (Solihatin, 2011: 23). Salah satu media yang dapat digunakan adalah media gambar. Media gambar merupakan gambar jadi termasuk foto, dan sesuatu gambar yang dicetak atau diprint disebuah kertas, bentuk visual dan dapat ditemukan dari berbagai sumber (Arsyad, 2013: 109). Berdasarkan uraian 
tersebut maka peneliti bermaksud melakukan penelitian yang berjudul "Pengaruh Metode Group to Group Exchange Berbantuan Media Gambar terhadap Hasil Belajar Kognitif Siswa pada Materi Ekosistem di Kelas VII Sekolah Menengah Pertama Negeri 4 Sekadau Hilir Tahun Pelajaran 2016/2017"

\section{METODE PENELITIAN}

Pendekatan pada penelitian ini adalah pendekatan kuantitatif. Adapun metode yang digunakan dalam penelitian ini adalah metode eksperimen. Bentuk penelitian yang digunakan dalam penelitian ini yaitu Quasi Exprimental Design dengan rancangan penelitian Nonequivalent Control Group Design. Populasi penelitian ini adalah seluruh siswa kelas VII Sekolah Menengah Pertama Negeri 4 Sekadau Hilir yang berjumlah 57 siswa.

Sampel penelitian ini diambil secara Sampling jenuh. "Teknik penentuan sampel dengan pertimbangan tertentu" (Sugiyono, 20013:124).Alasan peneliti memilih Sampling jenuh karena jumlah populasi relative kecil, atau kurang dari 30 orang dan jumlah siswa kelas VII A dan VII B kurang dari 30 orang.

Variabel dalam penelitian ini dibedakan menjadi 2 jenis, yaitu variabel Bebas dan variable terikat. Variabel bebas adalah metode pembelajaran "Group To Group Exchange (GGE) dan Media Gambar" dan variabel terikat adalah "Hasil Belajar Kognitif".

\section{HASIL PENELITIAN}

Hasil analisis lembar observasi guru di kelas eksprimen dalam proses pembelajaran didapatkan hasil pada pertemuan pertama yaitu $100 \%$ dan hasil pada pertemuan kedua yaitu $100 \%$. Dari kedua hasil pertemuan tersebut diperoleh angka yang berada pada rentang $81 \%-100 \%$ sehingga berkriteria sangat kuat.

Observasi siswa di kelas eksprimen pada pertemuan pertama $100 \%$ dan pertemua kedua $100 \%$. Adapun nilai rata-rata dari pertemuan pertama dan kedua menunjukan berkriteria sangat kuat yang artinya siswa dapat mengikuti kegiatan pembelajaran dengan sangat baik.

Keterlaksanaan observasi guru di kelas kontrol pada pertemuan pertama $100 \%$ dan pertemuan kedua $100 \%$. Rata-rata hasil pengamatan dari kedua pertemuan tersebut berada pada rentang $81 \%-100 \%$ sehingga berkriteria sangat kuat

Nilai hasil observasi siswa di kelas kontrol pada pertemuan pertama $100 \%$ dan pertemuan kedua $100 \%$. Rata-rata dari pertemuan pertama dan kedua tersebut adalah $100 \%$. Berdasarkan rata-rata presentase pertemuan pertama dan kedua menunjukkan kriteria sangat kuat.

Nilai belajar siswa diperoleh dari skor yang dicapai dibagi dengan jumlah total skor kemudian dikalikan nilai maksimal (seratus). Soal yang digunakan dalam kegiatan posttest adalah soal yang sama dengan soal pretest.

Pretest dilakukan untuk mengetahui kemampuan awal siswa pada materi ekosistem sebelum pembelajaran dilakukan di kelas eksperimen dan kontrol. Adapun Posttest dilakukan untuk mengetahui hasil belajar kognitif siswa pada materi ekosistem setelah proses pembelajaran menggunakan metode group to group exchange berbantuan media gambar dan di kelas kontrol menggunakan metode ceramah.

Berdasarkan pretest hasil belajar kognitif siswa pada materi ekosistem, diperoleh ratarata kelas sebesar 40,80 pada kelas Eksperimen. Pada kelas Kontrol diperoleh nilai rata-rata kelas sebesar 39,52. Data selengkapnya dapat dilihat pada tabel 1 berikut.

Tabel 1. Nilai Pretest Siswa

\begin{tabular}{cccccc}
\hline \multirow{2}{*}{ Kelas } & \multicolumn{2}{c}{ Nilai } & $\begin{array}{c}\text { Nilai } \\
\text { Rata-rata }\end{array}$ & $\begin{array}{c}\text { Jumlah } \\
\text { Siswa }\end{array}$ & Kategori \\
\cline { 2 - 5 } & Terendah & Tertinggi & \\
\hline Eksperimen & 25 & 70 & 40,80 & 28 & Rendah \\
Kontrol & 20 & 70 & 39,52 & 29 & Rendah \\
\hline
\end{tabular}


Sementara itu, hasil analisis data posttest kelas eksperimen diperoleh nilai rata-rata 84,93 dari 28 siswa. Adapun posttest kelas kontrol diperoleh nilai rata-rata 72,26 dari 29 siswa. Data selengkapnya dapat dilihat pada Tabel 2 berikut.

Tabel 2. Nilai Posttest Siswa

\begin{tabular}{cccccc}
\hline \multirow{2}{*}{ Kelas } & \multicolumn{2}{c}{ Nilai } & Nilai Rata- & $\begin{array}{c}\text { Jumlah } \\
\text { rata }\end{array}$ & Kategori \\
\cline { 2 - 3 } Siswa & Terendah & Tertinggi & & Tinggi \\
Eksperimen & 78 & 100 & 84,93 & 28 & Sedang \\
Kontrol & 60 & 80 & 72,26 & 29 & \\
\hline
\end{tabular}

Uji normalitas data dilakukan terhadap data pretest maupun posttest kelas VII A sebagai kelas eksperimen dan kelas VII B sebagai kelas kontrol dengan rumus chi-kuadrat. Tujuan dilakukannya uji normalitas adalah untuk mengetahui data berdistribusi normal atau berdistribusi tidak normal. Hasil uji normalitas dapat dilihat pada Tabel 3

Tabel 3. Hasil Uji Normalitas Kelas Eksperimen dan Kelas Kontrol

\begin{tabular}{|c|c|c|c|c|c|c|}
\hline $\begin{array}{r}\text { Data } \\
\text { yang dikaji }\end{array}$ & $\bar{X}$ & $D^{S}$ & $\begin{array}{c}\mathrm{X}^{2}{ }_{\text {Hitu }} \\
\mathrm{ng}\end{array}$ & $\underset{\text { abel }}{\mathrm{X}^{2} \mathrm{~T}}$ & A & Ket. \\
\hline $\begin{array}{l}\text { Pretest } \\
\text { Eksperimen }\end{array}$ & 40,80 & 12,41 & 17,93 & 7,81 & 0,05 & $\begin{array}{l}\text { Tidak } \\
\text { Normal }\end{array}$ \\
\hline $\begin{array}{l}\text { Pretest } \\
\text { Kontrol }\end{array}$ & 39,52 & 14,41 & 13,8 & 7,81 & 0,05 & $\begin{array}{l}\text { Tidak } \\
\text { Normal }\end{array}$ \\
\hline $\begin{array}{l}\text { Posttest } \\
\text { Eksperimen }\end{array}$ & 84,93 & 6,08 & 16,5 & 7,81 & 0,05 & $\begin{array}{l}\text { Tidak } \\
\text { Normal }\end{array}$ \\
\hline $\begin{array}{l}\text { Posttest } \\
\text { Kontrol }\end{array}$ & 72,26 & 6,67 & 10,55 & 7,81 & 0,05 & $\begin{array}{l}\text { Tidak } \\
\text { Normal }\end{array}$ \\
\hline
\end{tabular}

Berdasarkan Tabel 3 tersebut menunjukkan bahwa pada taraf signitifikan $\alpha=5 \%$ $(0,05), X^{2}{ }_{\text {hitung }}$ pretest kelas eksperimen sebesar $17,93>7,81\left(X^{2}\right.$ tabel) sehingga data dikatakan berdistribusi tidak normal. Pretest kelas kontrol sebesar 13,8 $>7,81$ ( $X^{2}$ tabel) yang artinya data berdistribusi tidak normal. Sementara itu, $X^{2}$ hitung posttest kelas eksperimen sebesar $16,5>7,81\left(\mathrm{X}^{2}\right.$ tabel) yang artinya data berdistribusi tidak normal. Adapun $\mathrm{X}^{2}$ hitung posttest kelas kontrol sebesar 10,55 >7,81 ( $\mathrm{X}^{2}$ tabel) artinya data berdistribusi tidak normal.

Pengujian hipotesis bertujuan untuk menjawab rumusan hipotesis penelitian yaitu apakah terdapat perbedaan yang signifikan hasil belajar kognitif antara siswa kelas eksperimen dan siswa kelas kontrol pada materi ekosistem di kelas VII A dan VII B Sekolah Menengah Pertama Negeri 4 Sekadau Hilir.

Pengujian hipotesis yang digunakan adalah uji statistik non-parametrik yaitu dengan menggunakan uji $U$ Mann Whitney untuk menguji data pretest dan posttest pada kelas eksperimen dan kelas kontrol. Adapun hasil uji $U$ Mann Whitney data pretest pada kelas eksperimen dan kelas kontrol dapat dilihat pada Tabel 4. 
Tabel 4. Hasil Uji Hipotesis Pretest dengan Uji U Mann Whithey

\begin{tabular}{cccccc}
\hline Kelas & $\mathbf{N}$ & $\mathbf{R}$ & $\mathbf{Z}_{\text {hitung }}$ & $\begin{array}{c}\mathbf{Z}_{\text {tabel }(\alpha=} \\
5 \%)\end{array}$ & Keterangan \\
\hline $\begin{array}{c}\text { Eksperimen } \\
\text { (VII A) }\end{array}$ & 28 & 864 & & & $\begin{array}{c}\text { Tidak Terdapat perbedaan } \\
\text { yang signitifikan hasil belajar } \\
\text { kognitif siswa pada }\end{array}$ \\
& & & $-0,83$ & $\begin{array}{c}1,96 \text { dan } \\
\text { pengukuran awal (pretest) }\end{array}$ & $\begin{array}{c}\text {-1,96 } \\
\text { antara kelas eksperimen dan } \\
\text { kelas kontrol di VII Sekolah } \\
\text { Menengah Pertama Negeri 4 } \\
\text { Kontrol } \\
\text { (VII B) }\end{array}$ \\
\hline
\end{tabular}

Diketahui bahwa nilai $Z_{\text {hitung }}$ adalah $-0,83$ sedangkan nilai $Z_{\text {tabel }}$ pada $\alpha=5 \%$ adalah \pm 1,96. Hal ini berarti nilai $-Z_{\text {tabel }}<Z_{\text {hitung }}<Z_{\text {tabel }}(-1,96<-0,83<1,96)$ maka $H_{0}$ diterima, yaitu Tidak terdapat perbedaan yang signifikan hasil belajar kognitif siswa antara kelas eksperimen dengan kelas kontrol di kelas VII SMP Negeri 4 Sekadau Hilir pada materi ekosistem sebelum pembelajaran (pretest). Hasiluji hipotesis data posttest pada kelas eksperimen dan kelas kontrol dengan menggunakan uji $U$ Mann Whitney dapat dilihat pada Tabel 5.

Tabel 5. Hasil Uji Hipotesis Posttest dengan Uji U Mann Whithey

\begin{tabular}{cccccc}
\hline Kelas & $\mathbf{N}$ & $\mathbf{R}$ & $\mathbf{Z}_{\text {hitung }}$ & $\mathbf{Z}_{\text {tabel }(\alpha=5 \%)}$ & Keterangan \\
\hline $\begin{array}{c}\text { Eksperimen } \\
\text { (VII A) }\end{array}$ & 28 & 1174,5 & & & $\begin{array}{c}\text { Terdapat perbedaan yang } \\
\text { signfikan penggunaan metode } \\
\text { group to group exchange } \\
\text { berbantuan media gambar } \\
\text { terhadap hasil belajar kognitif } \\
\text { siswa Sekolah Menengah }\end{array}$ \\
$\begin{array}{c}\text { Kontrol } \\
\text { (VII B) }\end{array}$ & 29 & 478,5 & $-5,79$ & $\begin{array}{c}1,96 \text { dan } \\
-1,96\end{array}$ & $\begin{array}{c}\text { Pertama Negeri 4 Sekadau Hilir. } \\
\text { (Posttest) }\end{array}$ \\
\hline
\end{tabular}

Diketahui nilai $Z_{\text {hitung }}$ adalah $-5,79$ sedangkan nilai $Z_{\text {tabel }}$ pada $\alpha=5 \%$ adalah $\pm-1,96$. Hal ini bearti nilai $Z_{\text {hitung }}<-Z_{\text {tabel }}$ yaitu $-5,79<-1,96$ maka $H_{a}$ diterima, yaitu terdapat perbedaan yang signfikan penggunaan metode group to group exchange berbantuan media gambar terhadap hasil belajar kognitif siswa Sekolah Menengah Pertama Negeri 4 Sekadau Hilir.

Hasil angket respon siswa di kelas eksperimen disebarkan setelah posttest selesai diberikan. Pemberian angket respon siswa ini bertujuan untuk mengetahui tanggapan atau respon siswa setelah belajar menggunakan metode group to group exchange berbantuan media gambar. Angket disebarkan oleh peneliti kepada 28 siswa.

Angket menggunakan skala likert yaitu terdapat pernyataan SS (5), S (4), RG (3), TS (2), dan STS (1). Selanjutnya pernyataan Persentase hasil angket respon siswa dapat dilihat pada Tabel 6 berikut. 
Tabel 6. Hasil Angket Respon Siswa

\begin{tabular}{|c|c|c|c|c|}
\hline Kelas & & $\begin{array}{l}\text { Butir } \\
\text { Angket }\end{array}$ & $\begin{array}{c}\text { Hasil } \\
\text { Angket }\end{array}$ & Kriteria \\
\hline $\begin{array}{l}\text { Eksperi } \\
\text { men }\end{array}$ & 8 & 10 & 85,92 & Sangat Kuat \\
\hline
\end{tabular}

\section{PEMBAHASAN}

Rata-rata pretest kelas eksperimen 40,80dimana 28 siswa atau 100\% yang mengikuti pretest ternyata tidak memenuhi kriteria ketuntasan minimal $(\mathrm{KKM}=75)$. Analisis hasil pretest menunjukkan bahwa kemampuan awal siswa di kelas eksperimen dalam menjawab soalsoal masih rendah. Semua siswa belum memenuhi kriteria ketuntasan minimal $(K K M=75)$. Hal ini dikarenakan tes awal (pretest) dilakukan untuk mengetahui pengetahuan dan kemampuan siswa terhadap materi yang akan disampaikan. Sementara itu, nilai rata-rata tes akhir (posttest) kelas ekpserimen sebesar 84,93dimana 100\% siswa yang mengikuti tes memenuhi kriteria ketuntasan minimal $(\mathrm{KKM}=75)$.

Hasil tes pada siswa kelas VII Sekolah Menengah Pertama Negeri 4 Sekadau Hilir sebagai kelas eksperimen pada saat posttest mengalami peningkatan. Perolehan nilai posttest yang baik tidak terlepas dari pengaruh metode Group to Group Exchange berbantuan media gambar. Hal ini terlihat pada proses pembelajaran dan diskusi kelompok, siswa aktif bertanya kepada kelompok yang presentasi jika tidak memahami materi yang disampaikan serta dapat menyimpulkan jawabannya.

Pemahaman materi yang baik oleh siswa berdampak terhadap peningkatan hasil belajar kognitif siswa. Pernyataan tersebut didukung oleh pendapat Silberman (2009: 105) yang mengatakan bahwa "Strategi pembelajaran aktif tipe Group to Group Exchange merupakan pembelajaran yang berpegang pada konsep belajar aktif (active learning) yang merupakan langkah cepat, menyenangkan, mendukung, dan menarik.

Hasil yang baik menunjukan bahwa siswa sangat menyukai dan mengikuti proses dari awal hingga akhir pembelajaran dengan baik. Hasil penelitian ini sejalan dengan penelitian Arini (2013) dengan judul "Pengaruh Strategi Pembelajaran Aktif Tipe Group to Group Exchange Terhadap Hasil Belajar matematika kelas V SD". Adanya penelitian menunjukkan bahwa Pembelajaran Aktif Tipe Group to Group Exchange dapat meningkatkan hasil belajar yang baik dan memperoleh hasil yang baik pula.

Rata-rata pretest kelas kontrol 39,52 dimana terdapat 29 atau 100\% siswa yang tidak memenuhi kriteria ketuntasan minimal $(\mathrm{KKM}=75)$. Rata-rata nilai pretest menunjukan bahwa siswa dalam menjawab soal-soal masih rendah. Kecendrungan siswa dalam mengolah informasi dan pengetahuan awal masih kurang.

Sementara itu, nilai rata-rata posttest kelas kontrol sebesar 72,26 dimana masih belum ada siswa atau $100 \%$ siswa belum memenuhi kriteria ketuntasan minimal $(\mathrm{KKM}=75)$. Hasil tes pada siswa kelas VII B Sekolah Menengah Pertama Negeri 4 Sekadau Hilir sebagai kelas kontrol mengalami kenaikan, namun masih dalam kategori "Rendah".

Hasil uji U Mann Whitney menunjukkan bahwa $-Z_{\text {tabel }}<Z_{\text {hitung }}<Z_{\text {tabel }}(-1,96<-0,83<$ 1,96), $\mathrm{H}_{0}$ diterima yaitu tidak terdapat perbedaan yang signitifikan hasil belajar kognitif siswa pada pengukuran awal (pretest) antara kelas eksperimen dan kelas kontrol di kelas VII Sekolah Menengah Pertama Negeri 4 Sekadau Hilir.

Sementara itu, Hasil uji $U$ Mann Whitney pada saat posttest menunjukkan bahwa $Z_{\text {hitung }}<-Z_{\text {tabel }}(-5,79<-1,96)$, maka $H_{a}$ diterima yaitu terdapat perbedaan yang signfikan penggunaan metode group to group exchange berbantuan media gambar terhadap hasil belajar kognitif siswa Sekolah Menengah Pertama Negeri 4 Sekadau Hilir. Adanya perbedaan yang signitifikan antara kelas eksperimen dan kelas kontrol menunjukan bahwa proses pembelajaran pada kedua kelas telah memberikan dampak yang berbeda terhadap pemerataan hasil belajar kognitif siswa.

Terdapat perbedaan hasil belajar di kelas eksperimen dan kelas kontrol hal ini dikarenakan kelas kontrol hanya menggunakan metode cerama. Artinya materi yang dikuasi 
siswa terbatas karena siswa kurang berperan aktif dalam proses pembelajaran, saat belajar banyak didominasi oleh guru sebagai fasilitator, siswa hanya mendengar serta diam saat guru menjelaskan dan bertanya keadaan ini membuat guru sukar melihat siswa yang lebih memahami materi pembelajaran. Hal ini didukung oleh pendapat Ayu (2008: 15) Metode ceramah hanya mengandalkan indra pendengar sebagai alat belajar yang paling dominan. Adapun kelemahan dalam metode ceramah siswa menjadi lebih pasif, bagi siswa yang kurang kemampuan menyimak akan susah memahami materi dan kurang memberikan kesempatan siswa untuk berpartisifasi. Hal tersebut membuat nilai siswa kelas kontrol lebih rendah dibandingkan kelas eksperimen. Hasil penelitian ini didukung oleh penelitan Murni (2008) dengan Judul penelitiaan "Penerapan Metode Belajar Aktif Tipe Group to Group Exchange (GGE) untuk Meningkatkan Hasil Belajar Matematika Siswa Kelas X IPS 1 MAN 2 Model Pekanbaru" yang menyatakan bahwa terdapat perbedaan antara kelas eksperimen dan kelas kontrol yang terlihat dari keaktifan siswa saat pembelajaran dan diskusi kelompok.

Angket disebarkan di kelas eksperimen setelah melaksanakan tes akhir pembelajaran (posttest) kepada 28 siswa.Persentase respon siswa secara keseluruhan adalah 85,92 \% dengan kriteria sangat kuat berada pada rentan $80 \%-100 \%$.

Hal ini menjelaskan bahwa respon siswa terhadap proses pembelajaran bernilai posistif, yang artinya siswa sangat tertarik pada pembelajaran menggunakan metode group to group exchange berbantuan media gambar dan sangat diminati. Hal ini dikarenakan metode group to group exchange berbantuan media gambar yang digunakan dapat membiasakan siswa berkerja sama dan bertanggung jawab didalam kelompok serta menumbuhkan rasa ingin tau siswa terhadap materi ekosistem.

\section{SIMPULAN}

Berdasarkan dari hasil penelitian yang telah diuraikan, dapat disimpulkan sebagai berikut:

1. Proses pembelajaran menggunakan metode group to group exchange berbantuan media gambar di kelas VII A Sekolah Menengah Pertama Negeri 4 Sekadau Hilir sebagai kelas eksperimen berjalan dengan sangat baik. Rata-rata persentase aktivitas gurudan siswa di kelas eksperimen masing-masing sebesar $100 \%$ dengan kriteria "Sangatkuat".

2. Proses pembelajaran menggunakan metode group to group exchange berbantuan media gambar di kelas eksperimen memperoleh hasilnilai rata-rata pretest sebesar 40,80 dan posttest sebesar 84,93.

3. Proses pembelajaran menggunakan metode ceramah di kelas kontrol memperoleh hasil nilai rata-rata pretest sebesar 39,52 dan posttest sebesar 72,26.

4. Tidak terdapat perbedaan yang signifikan hasil belajar kognitif siswa pada materi ekosistem pada pengukuran pretest antara kelas eksperimen dan kontrol berdasarkan hasil uji $U$ Mann Whitney $\left(-Z_{\text {tabel }}<\right.$ nitung $\left.<Z_{\text {tabel }}\right)$ yaitu $\left.-1,96<-0,83<1,96\right)$. Antara kelas eksprimen dengan kelas kontrol. Sementara itu, terdapat perbedaan yang signifikan hasil belajar kognitif siswa pada materi ekosistem pada pengukuran akhir (posttest) antara kelas eksperimen dan control berdasarkan hasil uji U Mann Whitney $\left(Z_{\text {hitung }}<-Z_{\text {tabel }}\right.$ yaitu $5,79<-1,96)$.

5. Respon siswa kelas VII A SMP Negeri 4 Sekadau Hilir proses pembelajaran dengan menggunakan metode group to group exchange berbantuan media gambar pada materi ekositem"Sangat kuat"dengan presentase 85,92\%

\section{REFERENSI}

Arsyad. (2013). Media pembelajaran. Edisi Revisi. Jakarta: Rajawali Pers

Rahmini, dkk. (2007). IPA TERPADU untuk SMP/MTs Kelas VII. Semarang: Aneka Ilmu

Rohimi. (2010). Pengaruh Penggunaan Media Gambar terhadap Hasil Belajar IImu Pengetahuan Sosial Siswa Kelas IV SDN 02 Korleko. Jurnal STKIP Hamzanwadi. Selong. 
Silberman. L. M. (2016). Active learning 101 cara belajar siswa aktif. Edisi Revisi. Bandung: Nuansa Cendekia

Sudjana, N. (2009). Penilaian Hasil Proses Belajar Mengajar. Bandung: Remaja Rosdakarya

Sugiyono. (2013). Penelitian Pendidikan (Pendekatan Kuantitatif, Kualitatif Dan R Dan D). Bandung: Alfabe

Triyanto, Rumiyati, Yuniari. (2011). Wajar penunjang program wajib belajar IPA Terpadu untuk SMP/MTs kelas VII semester II. Jakarta: Graha Pusta. 